\title{
ESR dating of tooth enamel in Mousterian Layer 20, El Castillo, Spain
}

\author{
Jonathan J. Liberda ${ }^{1}$ \\ Jeroen W. Thompson ${ }^{2}$ \\ W. Jack Rink ${ }^{1 \dagger}$ \\ Federico Bernaldo de Quirós ${ }^{3}$ \\ Rohit Jayaraman $^{1}$ \\ Kailash Selvaretinam ${ }^{1}$ \\ Kerry Chancellor-Maddison ${ }^{1}$ \\ Vito Volterra ${ }^{1}$ \\ ${ }^{1}$ School of Geography and Earth Sciences, McMaster University \\ ${ }^{2}$ Department of Medical Physics and Applied Radiation Sciences, McMaster University \\ ${ }^{3}$ Area de Prehistoria, Universidad de Leon, Campus de Vegazana \\ †Corresponding Author : rinkwj@mcmaster.ca
}

\begin{abstract}
Nine faunal teeth from Layer 20 of El Castillo cave in Cantabrian Spain were dated using electron spin resonance (ESR). Two teeth were rejected due to inconsistent sub-sample ages, while the remaining teeth yielded a mean age that is consistent with the stratigraphic expectations: $42.7 \pm 3.5$. Uncertainty in the external $\gamma$ dose rate results in a potential systematic uncertainty of $\pm 6.4 \mathrm{ka}$ that should affect all samples equally. The results provide independent confirmation of previously-reported ${ }^{14} \mathrm{C}$ ages for Layer 20 .
\end{abstract}

\section{Keywords:}

El Castillo

electron spin resonance (ESR)

electron paramagnetic resonance (EPR)

tooth enamel

Mousterian

Aurignacian 


\section{Introduction}

The deposits in El Castillo cave provide one of the longest and most complete archaeological sequences in Europe (Cabrera Valdés, Hoyos Gómez, \& Bernaldo de Quirós, 1997). Electron spin resonance (ESR) dating at El Castillo has been used to support a relatively early timing for the Middle to Upper Paleolithic transition in Cantabrian Spain (Rink, Schwarcz, \& Lee, 1997), as well as to directly compare ESR age results with ${ }^{14} \mathrm{C}$ ages (Rink, Schwarcz, \& Lee, 1996). Here we report ESR age results for tooth enamel from the Mousterian Layer 20.

Dating studies at El Castillo have been used in the past to support a relatively early timing for the Middle to Upper Paleolithic transition in Cantabrian Spain (Rink, Schwarcz, \& Lee, 1997). However, this view has been superseded by a model of regional transition is a "mosaic" in time and space (Straus, 1996). Indeed, quantitative dating of the Middle to Upper Paleolithic transition in the El Castillo sequence only is a challenge (Zilhão, J., 2006). The basal Aurignacian level (18) has been interpreted as

containing both Middle and Upper Paleolithic components, a conclusion supported by ${ }^{14} \mathrm{C}$ dates in excess of $46 \mathrm{ky}$ cal BP (Stuart, 2005). Separated by a sterile intercalating layer (19), the underlying Mousterian level (20) has been dated to 43.6 and $47.3 \mathrm{ky}$ cal BP (Cabrera-Valdés, et al., 1996; Zilhão, 2006), while Mousterian layers 21 and 22 have been dated with ESR to $70 \pm 8 \mathrm{ka}$.

ESR dating of fossil tooth enamel is well-established technique for dating sites at or beyond the limit of radiocarbon dating (Rink, 1997). The technique is based on the measurement of radiation dose in tooth enamel (hydroxyapatite); the ratio of absorbed dose to dose rate gives the burial age of the tooth. Age uncertainties are typically $\pm 10 \%$, including random uncertainties in the ESR measurement as well as unknown systematic uncertainties such as sediment moisture content and inhomogeneity of radiation doses (Grün, 2006).

In addition, dental tissues may incorporate significant concentrations of uranium due to transport by groundwater. It is therefore necessary to model the changing dose rate to the enamel. Typically, two model ESR are reported, according to an assumed uptake of uranium in the dental tissues: the early-uptake (EU) model assumes that all uranium present in the dental tissues was incorporated immediately following burial, while the linear-uptake (LU) assumes the concentration of exogenous uranium increased linearly over time. Other uptake models, including uranium loss or episodic uptake and loss, are also possible, but are rarely reported. In many cases, the dental tissues contain little or no uranium; in these cases, the EU and LU ages are indistinguishable.

\section{Methods}

The results from this study are for teeth collected from squares N-18, N-17, and N-16. All squares examined here were first excavated in 1980. Figure 1 shows the profile of the squares N-16 to N-18 from which teeth were extracted in this study. The teeth examined in this study were from Layers 20c, 20d, and 20e. 
Sample preparation and ESR measurement procedures followed standard techniques (Rink, 1994). If sediment was attached to the teeth, the closest $2 \mathrm{~mm}$ was collected for $\beta$ dose rate determination. During the process of $\alpha$ dose removal, enamel thickness was measured in at least 100 points to ensure $40 \mu \mathrm{m}$ enamel was removed from both the buccal and lingual sides of the enamel sample. Uranium (U) concentrations were determined by delayed neutron counting or ICP-MS, while thorium (Th) and potassium (K) concentrations were determined by neutron activation analysis or ICP-MS (see Table 1a).

In order to determine the annual external $\gamma$ dose rate to the teeth, concentrations of uranium, thorium, and potassium were determined in sediment excavated from three cores taken $5-20 \mathrm{~cm}$ into the face of layer 20 . Whole sediment, including a representative quantity of limestone, was ground and sampled. An average concentration of each radioisotope was calculated from the three cores. This concentration was used to determine the external $\gamma$ dose rate to the enamel using ROSY software. The external $\gamma$ dose rate was determined to be $515 \mu \mathrm{Gy} / \mathrm{a}$. The cosmic dose rate was also calculated using ROSY software and determined to be $55 \mu \mathrm{Gy} / \mathrm{yr}$ based upon a depth of $11 \mathrm{~m}$ for an overburden density of $2 \mathrm{~g} / \mathrm{cm}^{3}$. The average moisture content of the sediment was taken as 33\% based upon measurements in layer 20 at El Castillo. Because of the possible variation in sediment moisture (which affects dose rate) and radioisotope concentration, the dose rate uncertainty was estimated to be $20 \%$ of the annual dose rate. Therefore the tooth samples had their ages calculated using a dose rate of $570 \pm 114 \mu \mathrm{Gy} / \mathrm{a}$.

ESR measurements were performed using a JEOL JES-FA $100 \mathrm{X}$-band ESR spectrometer. The ESR spectrometer had the following settings: power: $2.0 \mathrm{~mW}$, amplitude: $0.5 \mathrm{mT}$, centre field: $336.0 \mathrm{mT}$, scan width: $5.0 \mathrm{mT}$, scan rate: $0.167 \mathrm{mT} / \mathrm{s}$, time constant $0.1 \mathrm{~s}$. ESR ages were calculated with ROSY v2.0 which includes onegroup theory for $\beta$ particle transport (Brennan, et al., 1997).

\section{Results}

Nine enamel samples and three additional sub-samples were dated from Layer 20. ESR analytical data, including radioisotope concentrations, are shown in Table 1a. Dose rates and ages are shown in Table $1 \mathrm{~b}$.

Ages are calculated for both the early uptake (EU) and linear-uptake (LU) models (Grün, Schwarcz, \& Chadam, 1988), in which it is assumed, respectively, that the uranium in the dental tissues was absorbed immediately following burial or at a constant rate since deposition. However, the low concentration of uranium in the dental tissues results in negligible differences between the EU and LU model ages. The following discussion will utilize LU ages only.

The uncertainties in the ages (approximately $\pm 20 \%$ ) are larger than is typical for ESR dating. For the samples analyzed here, the age calculation is dominated by the $\gamma$ dose rate (see Table 1b). The calculated $\gamma$ dose rate is strongly dependent upon the moisture 
content for the sediment surrounding the tooth sample. The moisture content of the soil used here (33\%) was measured directly in Layer 20 and assumed to be constant over time (Rink, Schwarcz, \& Lee, 1997).

Two sub-samples each were collected from three teeth $(97131,97137$, and CST1A; see Table 1a). The LU ages for 97131A and 97131B agree (44.7 \pm 9.0 ka compared with $43.3 \pm 9.2 \mathrm{ka}$ ). However, the LU ages for the sub-samples of 97137 and CST1A do not agree $(32.3 \pm 5.9 \mathrm{ka}$ and $39.6 \pm 7.9 \mathrm{ka} ; 47.0 \pm 9.4 \mathrm{ka}$ and $38.6 \pm 5.7 \mathrm{ka})$. Note that the stated uncertainty includes a large proportion of the $\gamma$ dose rate, which is an unknown systematic uncertainty that will be identical for sub-samples of a single tooth. Thus, although the stated uncertainties overlap, the sub-sample ages are nonetheless inconsistent.

The inconsistency of the sub-sample ages for 97137 and CST1A may be due to fragmentation of the cementum layer. For both teeth, only one sub-sample still includes attached cementum. The enamel sub-sample without attached cementum receives a calculated sediment $\beta$ dose rate that is significantly greater than that received by the subsample with attached cementum; thus, the age of the sub-sample without attached cementum is depressed compared to the age of the sub-sample with cementum. Additionally, the comparably high $U$ concentration in the attached sediment for CST1A may indicate weathering of the cementum. It is impossible to determine which subsample age is more reliable. Therefore, we exclude the ages from 97137 and CST1 from further discussion.

The mean age of all 8 remaining enamel samples is 42.7 , with a standard deviation of 3.5 $\mathrm{ka}$. However, the age calculation is dominated by the external $\gamma$ dose rate, which is subject to an unknown systematic error.

The external $\gamma$ dose rate contribution ranges between $70-85 \%$ of the total $\gamma$ dose rate, with mean $77 \%$. As we have assumed a systematic uncertainty of $\pm 20 \%$ to the external $\gamma$ dose rate, we believe it is appropriate to assume a systematic uncertainty of approximately $\pm 15 \%$ in the mean age of Layer 20 . Thus, we may quote the mean age of Layer 20 as $42.7 \pm 3.5 \pm 6.4 \mathrm{ka}$, where the first uncertainty refers to the standard deviation and the second uncertainty refers to the systematic uncertainty in the unknown external $\gamma$

dose rate. Note that the distinction between "random" and "systematic" uncertainty is not entirely precise, as the random component may include age variations due to unrecognized systematic uncertainties.

The ESR ages presented here are consistent with previously-reported ${ }^{14} \mathrm{C}$ ages of faunal remains in the same layer (Cabrera-Valdés, et al., 1996; Zilhao, 2006).

\section{Conclusions}

Twelve enamel samples were prepared from nine teeth collected from Layers $20 \mathrm{c}, 20 \mathrm{~d}$, and 20e at El Castillo Cave. Two samples were rejected from consideration due to inconsistent sub-sample ages, possibly due to degradation of cementum. The mean age 
of the remaining 8 samples is $42.7 \pm 3.5 \pm 6.4 \mathrm{ka}$, which includes the random and systematic uncertainties, respectively.

The uncertainty of the external $\gamma$ dose rate is by far the largest contributor to the uncertainty of the ages reported here. This uncertainty $( \pm 20 \%)$ is an unknown systematic error, which may be reduced potentially through future measurements of the $\gamma$ dose rate in situ. The ESR age results presented here provide independent confirmation of the ${ }^{14} \mathrm{C}$ dating results previously reported.

\section{Acknowledgements}

The authors would like to thank A. Pidruczny, J. Johnson, and R. Marsh for help with NAA and sample preparation, and the constructive comments of three anonymous reviewers which greatly improved the manuscript. We also thank the Natural Sciences and Engineering Council of Canada for financial support to WJR. 


\section{References}

Brennan, B.J., Rink, W.J., McGuirl, E.I., Schwarcz, H.P., \& Prestwich, W.V. (1997). Beta doses in tooth enamel by "one-group" theory and the ROSY ESR dating software. Radiation Measurements, 27, 307-314.

Cabrera Valdés, V., Hoyos Gómez, M., \& Bernaldo de Quirós, F. (1997). The transition from the Middle to Upper Paleolithic in the Cave of El Castillo (Cantabria, Spain). In Clark, G.A., \& Willermet, C.M. (Eds.), Conceptual issues in modern human origins research (pp. 177-188). Aldine de Gruyter: New York.

Cabrera-Valdés, V., Valladas, H., Bernaldo de Quiros, F., \& Hoyos Gomez, M. (1996). La transition Paléolithique moyen-Paléolithique supérieur à El Castillo (Cantabrie): nouvelles datations par le carbone-14. Comptes Rendus de l'Académie des Sciences Paris, 322, 1093-1098.

Grün, R. (2006). Direct dating of human fossils. Yearbook of Physical Anthropology, $49,2-48$.

Grün, R, Schwarcz, H.P., \& Chadam, J. (1988). ESR dating of tooth enamel: coupled correction for U-uptake and U-series disequilibrium. Nuclear Tracks and Radiation Measurements, 14. 237-241.

Maíllo Fernández, J.M., Cabrera-Valdès, V., \& Bernaldo de Quirós, F. (2004). Le débitage lamellaire dans le Moustérien final de Cantabrie (Espagne): le cas de El Castillo et Cueva Morin. L'anthropologie, 108, 367-393.

Rink, W.J., Schwarcz, H.P., Grün, R., Yalçinkaya, I., Taskiran, H., Otte, M., Valladas, H., Mercier, N., Bar-Yosef, O., and Kozlowski, J. (1994). ESR dating of the last interglacial Mousterian at Karaïn Cave, southern Turkey. Journal of Archaeological Science, 21, 839-849.

Rink, W.J. (1997). Electron spin resonance (ESR) dating and ESR applications in Quaternary science and archaeometry. Radiation Measurements, 27, 975-1025.

Rink, W.J., Schwarcz, H.P., \& Lee, H.K., Cabrera Valdés, V., Bernaldo de Quirós, F., \& Hoyos, M. (1997). ESR dating of Mousterian levels at El Castillo Cave, Cantabria, Spain. Journal of Archaeological Science, 24, 593-600.

Rink, W.J., Schwarcz, H.P., Lee, H.K., Cabrera Valdés, V., Bernaldo de Quirós, F., \& Hoyos, M. (1996). ESR dating of tooth enamel: Comparison with AMS ${ }^{14} \mathrm{C}$ at El Castillo Cave, Spain. Journal of Archaeological Science, 23, 945-951.

Straus, L.G. (1996). Continuity or rupture, convergence or invasion, adaptation or catastrophe, mosaic or monolithic: Views on the Middle to Upper Paleolithic transition in Iberia. In Carbonell, E. \&Vaquero, M. (Eds.), The last Neandertals, the first anatomically 
modern humans: A tale about the human diversity, cultural change and human evolution: The crisis at 40 ka B.P. (pp. 203-218). Tarragona: Universitat Rovita i Virgili.

Stuart, A.J. (2005). The extinction of woolly mammoth (Mammuthus primigenius) and straight-tusked elephant (Palaeoloxodon antiquus) in Europe. Quaternary International, 126-128, 171-177.

Zilhão, J. (2006). Chronostratigraphy of the Middle-to-Upper Paleolithic transition in the Iberian peninsula. Pyrenae, 37, 7-84. 


\section{Figures}

Figure 1. Stratigraphy of layers 17-21 along squares N-16 to N-18 (after Maillo Fernández, et al., 2004). Insert at upper left shows location of El Castillo in Spain.
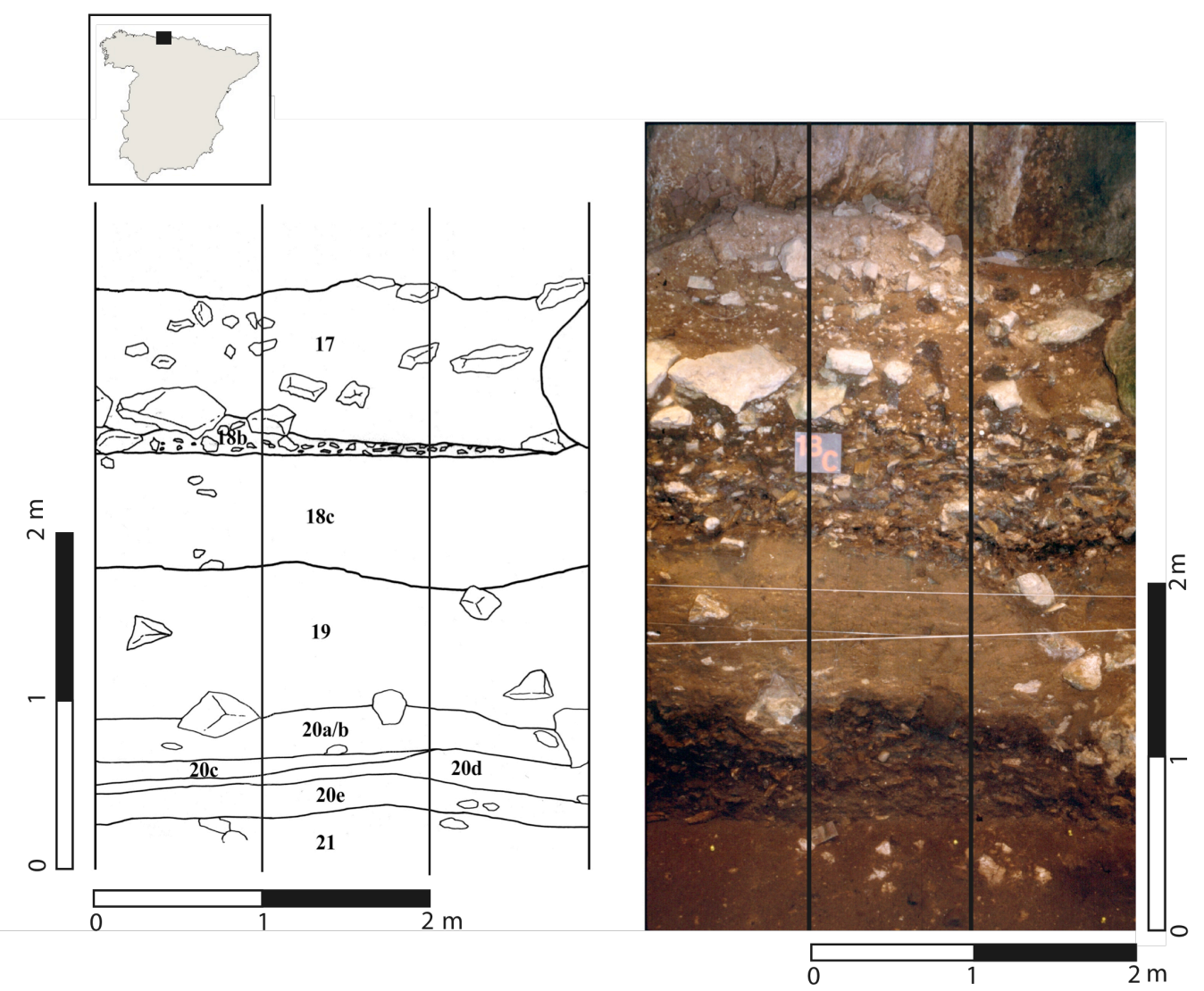